\title{
Kelangsungan Hidup Ikan setelah Meloloskan Diri pada Alat Tangkap Bubu di Perairan Desa Wakal, Kabupaten Maluku Tengah
}

\author{
Kedswin Gerson Hehanussa1*, Stany Rachel Siahainenia', Jacobus Bunga Paillin', \\ Ruslan Husen Saban Tawari ${ }^{1}$, Haruna ${ }^{1}$, dan Mochammad Riyanto ${ }^{2}$ \\ IJurusan Pemanfaatan Sumberdaya Perikanan, Fakultas Perikanan dan Ilmu Kelautan, \\ Universitas Pattimura \\ Jl. Mr. Chr. Soplanit Kampus Poka, Ambon Maluku 97234 Indonesia \\ 2Jurusan Pemanfaatan Sumberdaya Perikanan, Fakultas Perikanan dan llmu Kelautan, IPB University \\ Jl. Raya Dramaga Kampus IPB Dramaga Bogor, Jawa Barat 16680 Indonesia \\ Email: kedswinhehanussa@gmail.com
}

\begin{abstract}
The Survival of Fish after Escape to The Pot Waterways in Wakal Village, Central Maluku Regency

Fishermen in Wakal Village still water is pot to catch coral fish species. The pot is made from woven bamboo with small hexagonal-shaped cracks. The type of fish that are targeted by the catch usually after being caught in the traps suffer injuries to their bodies as they try to escape through small gaps that are hexagonal. The purpose of this study is to analyze the viability of fish after escaping to the cover net. The data were collected by experimental fishing using four units of pots that were cover net in 20 repetitions. The research was conducted from September to December 2018 in Wakal Village, and Central Maluku Regency. The total number of fish caught is only 2.83\% of fish that escape into the net cover. Fish that escaped are divided into 7 species including Plectrypops lima, Pinjalo lewisi, Ephinephelus tauvina, Chaetodon kleini, Centropyge bicolor, Priolepis cincta, Paraluteres prionurus. The cause of fish death is not only assessed from the wounds on the body of the fish when escaping or the wounds resulting from contact with other fish but the stress from the fish itself. The environmental factors that greatly affect the survival of fish when escaping are temperature and salinity.
\end{abstract}

Keywords: coral fish; cover net; survival of fish; pot; wakal village

\begin{abstract}
Abstrak
Nelayan di Perairan Desa Wakal menggunakan alat tangkap bubu untuk menangkap ikan karang. Bubu terbuat dari anyaman bambu dengan celah-celah berukuran kecil berbentuk hexagonal. Jenis ikan yang menjadi target tangkapan biasanya setelah tertangkap oleh bubu mengalami luka pada tubuhnya karena berupaya meloloskan diri melalui celah-celah kecil yang berbentuk hexagonal. Luka yang terdapat pada tubuh ikan dapat mengakibatkan kondisi yang buruk bagi kelangsungan hidup. Tujuan dari penelitian ini adalah Menganalisis kelangsungan hidup ikan setelah meloloskan diri ke cover net. Pengumpulan data dilakukan dengan uji coba penangkapan menggunakan 4 unit bubu buton yang dipasang cover net sebanyak 20 kali ulangan. Penelitian dilakukan pada bulan September-Desember 2018 di Desa Wakal, Kabupaten Maluku Tengah. Total jumlah keseluruhan ikan yang tertangkap hanya $2.83 \%$ ikan yang meloloskan diri masuk ke dalam cover net. Ikan yang lolos terbagi dalam 7 spesies diantaranya Plectrypops lima, Pinjalo lewisi, Ephinephelus tauvina, Chaetodon kleini, Centropyge bicolor, Priolepis cincta, Paraluteres prionurus. Penyebab kematian ikan bukan saja dinilai dari luka pada tubuh ikan saat meloloskan diri ataupun luka akibat dari kontak dengan ikan lainnya namun stress dari ikan itu sendiri. Adapun faktor-faktor lingkungan yang sangat berpengaruh terhadap kelangsungan hidup ikan saat meloloskan diri yaitu suhu dan salinitas.
\end{abstract}

Kata Kunci: bubu; Cover net; Desa wakal; Ikan karang; Kelangsungan hidup ikan 


\section{PENDAHULUAN}

Nelayan di Perairan Kabupaten Maluku Tengah pada umumnya menggunakan bubu sebagai alat untuk menangkap ikan karang, dengan alasan biaya yang dikeluarkan untuk membuat dan mengoperasikan alat tangkap relatif murah. Menurut Sudirman dan Mallawa (2004) bubu merupakan alat penangkap ikan yang dipasang secara tetap dalam air untuk jangka waktu tertentu yang memudahkan ikan masuk dan sulit keluar. Secara umum bentuk bubu sangat beragam seperti: segi empat, trapesium, silinder, lonjong, bulat setengah lingkaran, persegi panjang, atau bentuk lainnya (Martasuganda 2008).

Konstruksi bubu yang digunakan oleh nelayan saat ini sangat mempengaruhi sumberdaya yang ada. Hal ini disebabkan oleh penggunaan alat tangkap bubu yang sering kali menangkap spesies target berukuran kecil atau belum layak tangkap. Jenis ikan yang menjadi target tangkapan biasanya setelah tertangkap oleh bubu mengalami luka pada tubuhnya karena berupaya meloloskan diri melalui celah-celah kecil yang berbentuk hexagonal. Luka yang terdapat pada tubuh ikan dapat mengakibatkan kondisi yang buruk bagi kelangsungan hidup seperti berkurangnya kemampuan reproduksi (Raby et al. 2014), menurunnya laju pertumbuhan (Davis 1981), berkurangnya kemampuan mempertahankan diri (Ryer et al. 2004), dan berkurangnya kemampuan mencari makan bahkan kematian (Smith \& Hines 1991).
Kondisi seperti ini sering kali sangat bertentangan dengan amanat Code of Conduct for Responssible Fisheries (CCRF). Pada dasarnya bubu yang digunakan oleh nelayan di Perairan Kabupaten Maluku Tengah belum efektif. Oleh karena itu, untuk menanggapi permasalahan di atas maka perlu dilakukan penelitian tentang kelangsungan hidup ikan saat meloloskan diri dari alat tangkap dengan menggunakan metode cover net. Penelitian mengenai kelangsungan hidup ikan telah dilakukan pada beberapa alat penangkapan ikan seperti Trawl (Lehtonen et al. 1998), Long line (Milliken et al., 1999; kerstetter \& Graves 2006), Trammel net (Purbayanto et al. 2000), Gillnet (Haegen et al. 2004), Purse seine (Missund 2000). Namun, objek yang menjadi penelitian ini merupakan ikan-ikan pelagis yang bertahan hidup dalam waktu 5 sampai 30 hari serta masih bersifat eksploratif. Oleh karena itu, perlu dilakukan penelitian yang lebih spesifik terhadap alat tangkap yang bersifat perangkap dengan spesies target ikan karang. Tujuan penelitian ini adalah Melihat kelangsungan hidup ikan karang setelah meloloskan diri ke cover net. Penelitian ini belum dilakukan sehingga diharapkan hasil dari peneltian ini menjadii informasi awal.

\section{MATERI DAN METODE}

Penelitian dilakukan pada bulan September-Desember 2018 di perairan Desa Wakal, Kecamatan Leihitu, Kabupaten Maluku Tengah (Gambar 1).

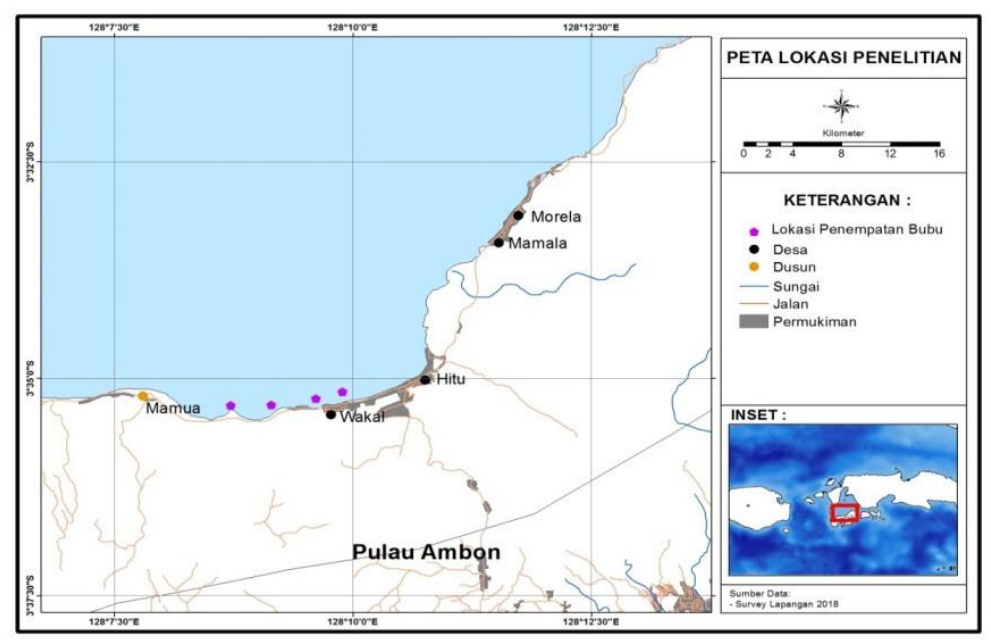

Gambar 1. Peta lokasi penelitian 
Penelitian menggunakan experimental fishing method dengan mengoperasikan empat unit bubu buton yang dilengkapi dengan cover net. Lama waktu pengambilan data yaitu sebanyak 20 kali ulangan. Pemasangan cover net dibuat ke samping kiri, kanan dan atas sehingga ikanikan yang telah melewati mata bubu mudah masuk dan tertampung di cover net. Dengan cara ini dapat diketahui jumlah, jenis, serta yang lolos melalui mata bubu saat alat tangkap dioperasikan. Konstruksi cover net pada bubu yang digunakan disajikan pada Gambar 2.
Konstruksi cover net pada bagian samping kiri, kanan dan atas badan bubu. Berdasarkan tingkah laku ikan saat berada dalam bubu ikan akan mencari jalan keluar dengan cara menyusuri dinding-dinding bubu baik ke atas maupun ke samping sehingga peluang lolosnya ikan akan semakin besar. Ikan yang meloloskan diri melalui mesh size bubu dan tertampung pada cover net, diambil kemudian dimasukan ke dalam keramba jaring apung mini. Konstruksi keramba jaring apung mini yang digunakan disajikan pada Gambar 3.

Cover net

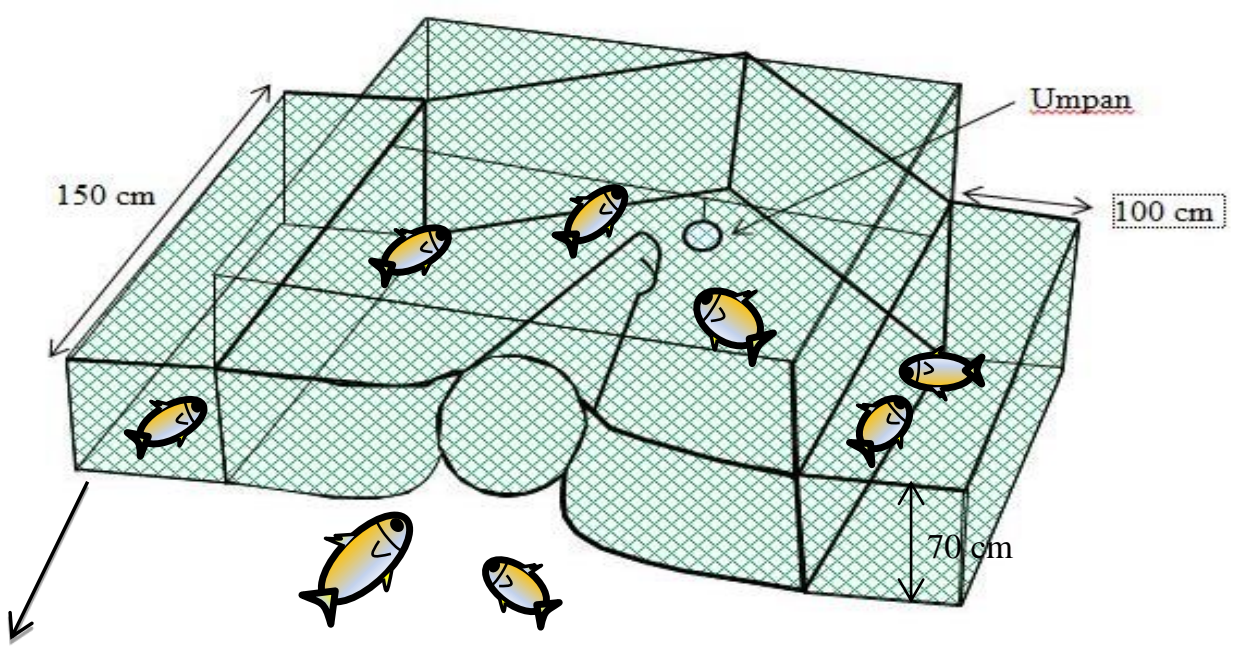

Gambar 2. Konstruksi cover net atau jaring pembungkus

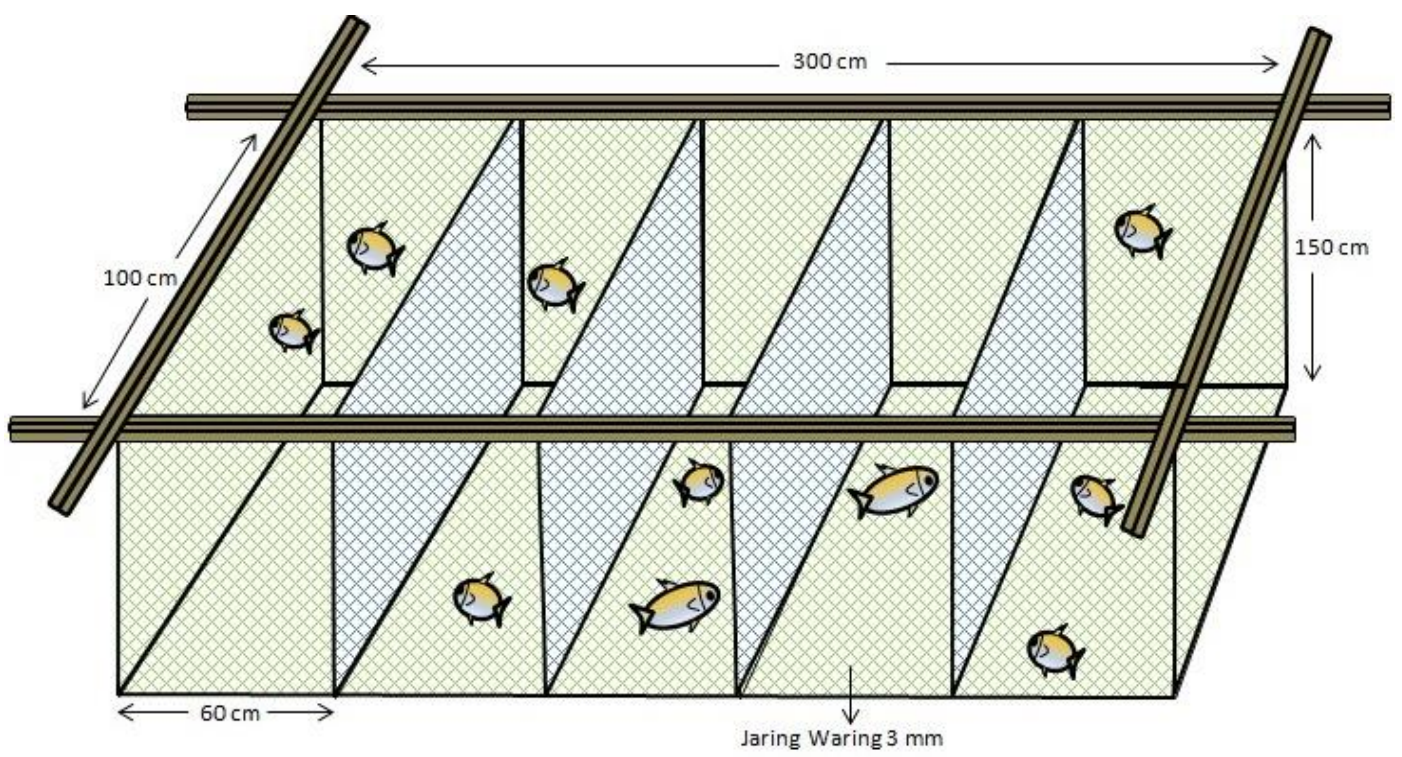

Gambar 3. Konstruksi Keramba Jaring Apung Mini 


\section{HASIL DAN PEMBAHASAN}

Jumlah total hasil tangkapan bubu selama penelitian sebanyak 353 individu dengan berat total $71.24 \mathrm{~kg}$. jumlah spesies yang tertangkap sebanyak 63 spesies yang terbagi dalam 22 famili antara lain jenis ikan kerapu (Serranidae), kakatua (Scaridae), Lalosi ekor kuning (Caesionidae), Kakap merah (Lutjanidae), bubara (Carangidae) dan jenis ikan karang lainnya. Hasil tangkapan dominan dari segi jumlah adalah Achanthuridae 83 individu (24.06\%), Scaridae 41 individu (18.88\%), Holocentridae 31 individu (8.99\%), Serranidae 25 individu $(7,25 \%)$ dan Lethrinidae 23 individu (6.67\%).

Dilihat dari jumlah spesies, maka hasil tangkapan yang dominan adalah Achanthurus nubilus 49 individu (14.29\%), Scarus russelli 24 individu (7\%), Plectrypops lima 24 individu (7\%), Lethrinus laticaudis 17 individu (4.95), dan Parupeneus rubescen 17 individu (4.95\%). Komposisi jumlah hasil tangkapan bubu yang dominan tertangkap disajikan pada Gambar 3.

Total jumlah keseluruhan ikan yang tertangkap hanya $2.83 \%$ ikan yang meloloskan diri masuk ke dalam cover net. Ikan yang lolos terbagi dalam 7 famili diantaranya famili Chaetodontidae 3 individu, Holochentridae 1 individu, Gobiidae 2 individu, Monachantidae 1 individu, Serranidae 1 individu, Lutjanidae 1 individu, dan Pomachantidae 1 individu. Dilihat dari segi ekonomisnya maka yang termasuk hasil tangkapan utama berjumlah 3 individu, diantaranya Plectrypops lima, Pinjalo lewisi, dan Ephinephelus tauvina. Ketiga spesies ini masing-masing dari famili Holochentridae, Lutjanidae, dan Serranidae sedangkan yang termasuk hasil tangkapan sampingan sebanyak 7 ekor diantaranya Chaetodon kleini 3 individu, Centropyge bicolor 1 individu, Priolepis cincta 2 individu, dan Paraluteres prionurus 1 individu. Dari 7 spesies masing-masing dari famili Chaetodontidae, Pomachantidae, Monachantidae, dan Gobiidae. Komposisi hasil tangkapan pada cover net disajikan pada Gambar 4.

Komposisi hasil tangkapan didominasi oleh famili Acanthuridae, Scaridae, Holocentridae, Serranidae, dan Lethrinidae. Hal ini berhubungan erat dengan lokasi pemasangan bubu di perairan karangberpasir dimana perairan karang merupakan tempat hidup bagi ikan-ikan yang mendiami tempat tersebut (Setiawan et al. 2013). Menurut Murdiyanto (2003) pada perairan karang terdapat famili ikan yang dominan antara lain Pomacentridae, Labridae, Serranidae, Apogonidae, Chaetodontidae, Scaridae, Acanthuridae, Blenniidae dan Gobiidae. Famili Acanthuridae memiliki keanekaragaman pola makan yang besar dengan memanfaatkan kelimpahan alga sebagai sumber makanan sehingga sebagian besar spesies Acanthurus adalah

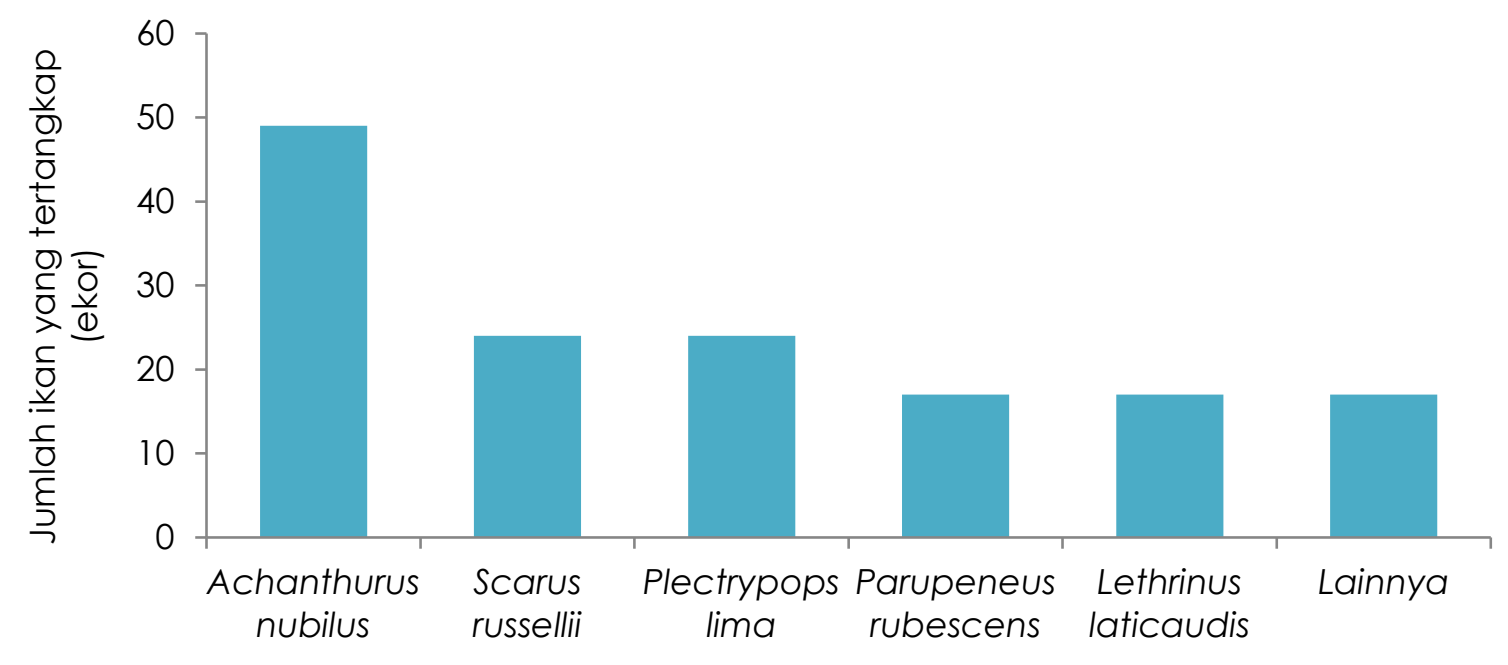

Jenis ikan yang dominan tertangkap

Gambar 3. Komposisi hasil tangkapan bubu yang dominan tertangkap berdasarkan jenis spesies. 


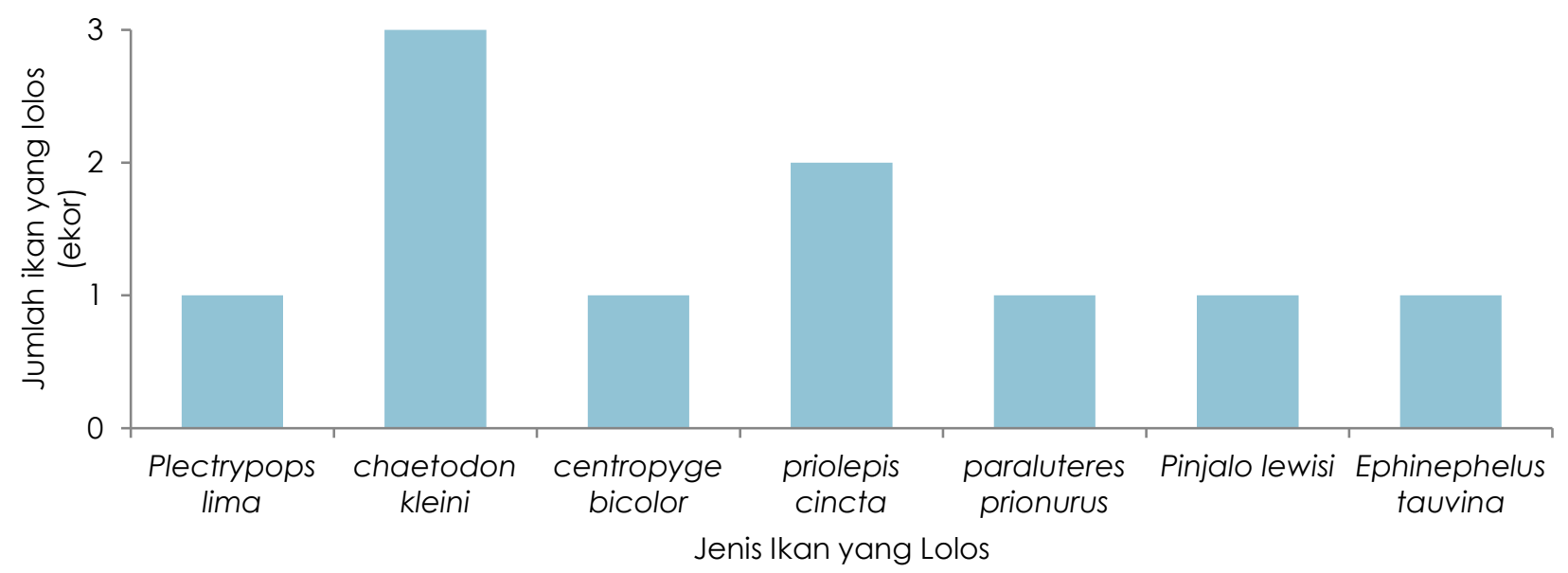

Gambar 4. Komposisi hasil tangkapan pada cover net

herbivora (Wibowo \& Adrim 2013). Hasil tangkapan lain yang dominan adalah Scaridae, Holocentridae, Serranidae, dan Lethrinidae. Ikan dari famili Scaridae, Hdan Lethrinidae merupakan Ikan diurnal yang aktif mencari makan pada waktu pada siang hari (Riyanto, 2011).

Hasil penelitian ini menunjukkan bahwa ukuran ikan yang tertangkap memiliki bentuk dan morfologi yang beragam. Kondisi ini disebabkan oleh ketersediaan sumberdaya ikan pada lokasi pemasangan bubu telah mengalami gejala over fishing sehingga jumlah hasil tangkapan yang tertangkap masih berukuran kecil. Jenis ikan yang lolos pada cover net merupakan bio indikator yang sangat berperan penting dalam proses pertumbuhan karang. Menurut Purwanto et al. (2019) Terumbu karang adalah bagian dari habitat dasar perairan laut dangkal yang merupakan pusat sumberdaya kompleks sehingga dapat mempengaruhi banyak aspek seperti perekonomian. Namun, dengan melihat kondisi yang ada perairan yang menjadi tempat pengoperasian alat tangkap telah terdegradasi akibat ulah manusia. Aktifitas penangkapan yang dilakukan terus-menerus sepanjang waktu mengakibatkan keadaan perairan menjadi tidak seimbang. Masalah lain yang ditemukan pada lokasi penempatan bubu adalah pencemaran akibat ulah manusia yang membuang limbah masyarakat secara sembarangan melalui sungai-sungai kecil maupun secara langsung ke laut. Masyarakat sekitar sering kali melakukan kegiatan penangkapan dengan menggunakan bahan peledak sehingga pada daerah tersebut terlihat banyak karang yang sudah sakit (rusak).

Total ikan yang mampu meloloskan diri dari alat tangkap pada umumnya hanya berjumlah 10 individu, diantaranya Chaetodon kleini sebanyak 3 individu $(0.85 \%)$, Priolepis cincta 2 individu (0.57\%), Plectrypops lima 1 individu (0.28\%), Centropyge bicolor 1 individu $(0.28 \%)$, Paraluteres prionurus 1 individu (0.28\%), Pinjalo lewisi 1 individu (0.28\%) dan Ephinephelus tauvina 1 individu (0.28\%). Selama proses pengamatan dalam jangka waktu lima hari mengalami penurunan jumlah. Penurunan jumlah ikan yang lolos terjadi pada hari kedua, tiga, dan empat. Perubahan tingkat kelangsungan hidup ikan pada jaring apung disajikan pada Tabel 1.

Tabel 1 memperlihatkan bahwa 10 ekor
ikan yang meloloskan diri sangat mempengaruhi kondisi tubuhnya. Salah satu jenis ikan yang ditemukan luka pada tubuhnya yaitu ikan Plectrypops lima, luka yang disebabkan oleh jeratan mesh size bubu berakibat pada tingkat kelangsungan hidupnya. Selama proses pengamatan ikan tersebut hanya mampu bertahan selama satu hari. Hal ini berbeda dengan ikan Priolepis cincta yang tanpa luka pada bagian tubuh tapi fakta di lapangan ikan tersebut hanya bertahan selama satu hari, sejalan dengan tidak adanya luka pada tubuh ikan pasca lolos dari alat tangkap 
adapun jenis ikan lain yang mampu bertahan selama dua sampai empat hari diantaranya jenis ikan Pinjalo lewisi, Priolepis cincta, Chaetodon kleini. Jenis ikan lain yang mampu bertahan selama lima hari yaitu ikan Chaetodon kleini dan Ephinephelus tauvina. Kedua jenis ikan ini mampu mempertahankan hidupnya selama proses pengamatan dengan kata lain tingkat kelangsungan hidup ikan pasca lolos dari alat tangkap dipengaruhi oleh kondisi luka pada tubuh ikan dan lingkungan sekitar.

Tingkat kelangsungan hidup dari masing-masing jenis ikan yang lolos pada umumnya berbeda, artinya bahwa ikan yang mati ataupun hidup bukan saja dipengaruhi oleh luka yang diakibatkan karena alat tangkap namun akibat dari stress ikan itu sendiri. Adanya luka akan mempengaruhi respons stress dan mortalitas pada ikan yang tertangkap (Purbayanto et al. 2010). Pada dasarnya penyebab luka fisik pada ikan akibat dari adanya gesekan alat tangkap sehingga mempercepat kematian ikan. Berdasarkan pengamatan, terdapat beberapa jenis ikan yang tidak terluka saat dimasukan kedalam keramba jaring apung, ternyata saat ditemukan ikan tersebut dalam keadaan mati. Hal ini mengindikasikan bahwa pada keramba jaring apung ada proses kanibalisme antara pemangsa dan yang dimangsa sehingga tingkat stress dari ikan itu sendiri akan menghambat kelangsungan hidupnya. Hal tersebut sejalan dengan Cook et al. (2019) luka fisik dan stress pada ikan bukan saja diakibatkan oleh alat tangkap itu sendiri tapi akibat dari kontak dengan ikan lain. Sebagian individu yang melarikan diri dari jaring kantong memiliki tingkat stress yang tinggi sehingga peluang ikan untuk dimangsa sangat mungkin (Ryer et al. 2004).

Berdasarkan hasil pengamatan ikan Plectrypops lima menunjukkan rasio kelangsungan hidup yang sangat rendah dengan tingkat stress yang cukup tinggi. Kelangsungan hidup ikan pasca lolos dari alat tangkap hanya mampu bertahan selama satu hari disebabkan luka pada bagian operculum. Rendahnya rasio kelangsungan hidup ikan dan tingginya stress dari ikan yang tertangkap disebabkan oleh terjerat lubang jaring. Gangguan fisiologi pada ikan yang diakibatkan oleh luka dapat menyebabkan kematian (Johansen et al., 2015, Bevelhimer et al., 2019). Pendapat yang sama juga disampaikan oleh Arami \& Mustafa (2010) rendahnya rasio survival bagi ikan-ikan yang tertangkap dapat disebabkan oleh kontak yang sempit (terjepit) pada lingkaran tubuh di sekitar operculum. Hal ini dapat mengganggu proses respirasi dan kerusakan tubuh serta menimbulkan stress ikan itu sendiri.

Hasil penelitian menunjukkan bahwa sebanyak 3 ekor ikan yang tanpa luka mampu bertahan hidup selama beberapa hari namun pada akhirnya mati, diantaranya adalah ikan Pinjalo lewisi selama dua hari

Tabel 1. Tingkat kelangsungan hidup ikan pasca lolos dari alat tangkap bubu

\begin{tabular}{cccccc}
\hline \multirow{2}{*}{ Jenis ikan } & \multicolumn{5}{c}{ Tingkat kelangsungan hidup ikan berdasarkan hari } \\
\cline { 2 - 6 } & Hari-ke 1 & Hari-ke 2 & Hari-ke 3 & Hari-ke 4 & Hari-ke 5 \\
\hline Plectrypops lima & $\boldsymbol{\sigma}$ & $\bullet$ & $\bullet$ & $\bullet$ & $\bullet$ \\
Chaetodon kleini & 0 & 0 & 0 & 0 & 0 \\
Centropyge bicolor & 0 & 0 & 0 & $\varnothing$ & $\bullet$ \\
Priolepis cincta & 0 & $\bullet$ & $\bullet$ & $\bullet$ & $\bullet$ \\
Paraluteres prionurus & 0 & 0 & 0 & 0 & 0 \\
Chaetodon kleini & 0 & 0 & 0 & 0 & 0 \\
Pinjalo lewisi & 0 & 0 & $\bullet$ & $\bullet$ & $\bullet$ \\
Priolepis cincta & 0 & 0 & 0 & $\bullet$ & $\bullet$ \\
Chaetodon kleini & 0 & 0 & 0 & 0 & $\bullet$ \\
Ephinephelus tauvina & 0 & 0 & 0 & 0 & 0 \\
\hline
\end{tabular}

Keterangan: $\bigcirc$ : hidup dan tidak luka; • : mati; $\varnothing$ : luka;, : luka dan mati 
Priolepis cincta selama tiga hari, dan Chaetodon kleini selama empat hari. Berdasarkan teori ikan-ikan tersebut berasosiasi pada daerah terumbu karang dengan suhu yang lebih rendah, saat dimasukan ke dalam keramba ikan-ikan tersebut akan merespon stress yang lebih tinggi sehingga keadaan ini menjadi tak terkendali. Dengan demikian, suhu perairan secara bersamaan dengan cepat berperan dalam tingkat kematian ikan. Menurut Allan (2015) temperatur yang tinggi menyebabkan menurunnya swimming performance. Perubahan suhu lingkungan akan menyebabkan stress pada organisme laut dan juga berpengaruh pada proses metabolisme (Hastuti et al. 2003). Sejalan dengan Kantun (2012) suhu merupakan faktor terpenting dalam organisme perairan, karena akan mempengaruhi aktivitas dan perkembangbiakan dari organisme perairan. Strategi konservasi yang efektif dalam dunia penangkapan yaitu menangkap dan melepaskan ikan pada suhu yang lebih rendah (Prystay et al. 2017). Tingkat pemulihan ikan pasca penangkapan akan lebih cepat seiring dengan menurunnya suhu perairan.

\section{KESIMPULAN}

Total jumlah keseluruhan ikan yang tertangkap hanya $2.83 \%$ ikan yang meloloskan diri masuk ke dalam cover net. Penyebab kematian ikan bukan saja dinilai dari luka pada tubuh ikan saat meloloskan diri ataupun luka akibat dari kontak dengan ikan lainnya namun stress dari ikan itu sendiri.

\section{DAFTAR PUSTAKA}

Allan, B. J., Domenici, P., Munday, P. L., \& McCormick, M. I. 2015. Feeling the heat: the effect of acute temperature changes on predator-prey interactions in coral reef fish. Conserv. Physiol., 3(1):1-12. doi: 10.1093/conphys/cov01 1

Bevelhimer, M. S., Pracheil, B. M., Fortner, A. M., Saylor, R., \& Deck, K. L. 2019. Mortality and injury assessment for three species of fish exposed to simulated turbine blade strike. Can. J. Fish. Aquat. Sci., 76(12): 2350-2363. doi: 10.1139/cjfas-2018-0386
Cook, K.V., Reid, A.J., Patterson, D.A., Robinson, K. A., Chapman, J. M., Hinch, S.G., \& Cooke, S.J. 2019. A synthesis to understand responses to capture stressors among fish discarded from commercial fisheries and options for mitigating their severity. Fish Fish., 20(1):25-43. doi: 10.1111 /faf.12322

Davis, G.E. 1981. Effects of injuries on spiny lobster, Panulirus argus and implications for fisheries management. Fisheries Bulletin. NOAA. 78:979-984.

Hastuti, S., Supriyono, E., Mokoginta, \& Subandiyo. 2003. Respon respon glukosa darah ikan gurami (Osporonemus gourami, lac) terhadap stres perubahan suhu lingkungan. J. Akuakultur Indo., 2(2): 73-77

Haegen, V.G.E., Ashbrook, C.E., Yi, K.W., \& Dixon, J.F. 2004. Survival of spring Chinook salmon captured and released in a selective commercial fishery using gill nets and tangle nets. Fish. Res., 68(1-3): 123-133 doi: 10.1016/j.fishres.2004.02.003.

Johansen, J.L., Steffensen, J.F., \& Jones, G.P. 2015. Winter temperatures decrease swimming performance and limit distributions of tropical damselfishes. J. Conserv. Physiol., 3(1):p.cov039. doi: 10.1093/conphys/cov039

Kantun, W. 2012. Suhu dan tingkah laku ikan tuna sirip kuning (Thunnus albacores) hubungannya dengan model pengelolaan. Stitek Balik Diwa 1-19p.

Kerstetter, D.W., \& Graves, J.E. 2006. Survival of white marlin (Tetrapturus albidus) released from commercial pelagic longline gear in the western North Atlantic. Fish. Bull. 104(3):434-444

Lehtonena, E.V., Tschernij \& Suuronen, P. 1998. An improved method for studying survival of fish that escape through meshes of trawl codends. Fish. Res., 38(3):303-306 doi : 10.1016/S0165-7836(98)00163-5

Martasuganda, S. 2008. Bubu (Traps). Departemen Pemanfaatan Sumberdaya Perikanan dan Pusat Kajian Sumberdaya Pesisir dan Lautan. Bogor (ID): Institut Pertanian Bogor. 8-44 Hal.

Milliken, H.O., Carr, H.A., Farrington, M., \& Lent, E. 1999. Survival of Atlantic cod (Gadus morhua) in the Northwest Atlantic longline fishery. J. Mar. Technol. Soc., 33(2):19-24. doi :10.4031/MTSJ.33.2.4 
Misund, O.A. \& Beltestad, A.K. 2000. Survival of mackerel and saithe that escape through sorting grids in purse seines. Fish. Res., 48(1):31-41. doi: 10.1016/S0165-7836 (00)00118-1

Murdiyanto, B. 2003. Mengenal, Memelihara dan Melestarikan Ekosistem Terumbu Karang. Jakarta (ID): COFISH Project. 53 $\mathrm{HIm}$.

Ozbilgin, H., \& Wardle, C.S. 2002. Effect of seasonal temperature changes on the escape behaviour of haddock, Melanogrammus aeglefinus, from the codend. Fish. Res., 58:323-331. doi: 10.10 16/S0165-7836(01)00394-0

Prystay, T.S., Eliason, E.J., Lawrence, M.J., Dick, M., Brownscombe, J.W., Patterson, D.A., \& Cooke, S.J. 2017. The influence of water temperature on sockeye salmon heart rate recovery following simulated fisheries interactions. Conservation physiology, 5(1):1-12. doi: 10.1093/conp hys/cox050

Purbayanto, A. \& Sondita, M.F.A. 2000. Perbaikan selektivitas jaring tramel dan survival ikan target muda dan hasil tangkap sampingan sebagai upaya konservasi keanekaragaman hayati laut. Bulletin PSP. 9(2):1-16.

Purbayanto, A., Riyanto, M., \& Fitri, A. D. P. 2010. Fisiologi dan Tingkah laku Ikan pada Perikanan Tangkap. Fakultas Perikanan dan IImU Kelautan IPB. IPB Press. Bogor (ID). 208 hal.

Purwanto, A.D., Setiawan, K.T., \& Ginting, D.N.B. 2019. Pemanfaatan Data Penginderaan Jauh untuk Ekstraksi Habitat Perairan Laut Dangkal di Pantai Pemuteran, Bali, Indonesia. J. Kelaut.
Trop., 22(2): 165-174. doi: 10.14710/jkt.v22 i2.5092

Raby, G.D., Packer, J.R., Danylchuk, A.J., \& Cooke, S.J. 2014. The understudied and underappreciated role of predation in the mortality of fish released from fishing gears. Fish Fish., 15(3):489-505. doi: 10.11 $11 /$ faf. 12033

Riyanto, M. 2011. Efektivitas penangkapan ikan kerapu macan (epinephelus fuscoguttatus) dengan bubu menggunakan umpan buatan. Harpodon Borne. 4(1): 21-32

Ryer, C. H., Ottmar, M. L., \& Sturm, E. A. 2004. Behavioral impairment after escape from trawl codends may not be limited to fragile fish species. Fisheries Research. 66:261-269 doi: 10.1016/\$0165-7836(03)00 197-8

Setiawan, F., Razak, T.B., Idris, \& Estradivaria. 2013. Komposisi spesies dan perubahan komunitas ikan karang di wilayah rehabilitasi ecoreef pulau manado tua, taman nasional bunaken. J. IImu Teknol. Kelaut. Trop., 5(2):377-390. doi: 10.29244/ jitkt.v5i2.7566

Smith, L.D., \& Hines, A.H. 1991. The effect of cheliped loss on blue crab Callinectes sapidus rathbun foraging rate on softshell clams Mya arenaria L. Exp. Mar. Biol. Ecol., 151 (2):245-256.

Sudirman, \& Mallawa, A. 2004. Teknik Penangkapan Ikan. Jakarta (ID) : Rineka Cipta. $186 \mathrm{Hal}$

Wibowo, K., \& Adrim, M. 2013. Komunitas ikanikan karang di teluk prigi trenggalek, jawa timur. J. Zoological Indo., 22(2): 2938. 